\title{
BRAND LOYALTY MODEL IN BALINESE VILLAGE AS AN ART AND CULTURAL TOURISM DESTINATION IN NATIONAL RURAL AREAS, CASE STUDY ON WANAGIRI KAUH VILLAGE, TABANAN
}

\author{
I Made Bayu Wisnawa, Putu Agus Prayogi, I Ketut Sutapa \\ STIPAR Triatma Jaya Badung, Indonesia \\ kerjabayu@gmail.com
}

\begin{abstract}
The village is an Indonesian wealth that has the potential to be developed in the tourism sector in realizing prosperity for all Indonesian people. However, there are still many resources in the village that are not well managed. This study aims to: i) identify tourism potential, ii) formulate strategies based on strengths, weaknesses, opportunities and threats, iii) formulate a brand loyalty model in Wanagiri Kauh Tabanan Bali Village in developing tourism as a village in the national rural area, iv) compile a village potential development plan towards rural tourism. The method used is quantitative and qualitative methods. The quantitative method uses Structural Equation Modeling to form a brand loyalty model with antecedents of Brand Image, Brand Awareness, Service Quality, and Customer Satisfaction. The number of samples is 200 tourists who have visited. Meanwhile, the qualitative methods used include SWOT, and in-depth interviews. The results showed that Wanagiri Kauh Village: i) has natural and cultural tourism potential, ii) tourism potential development strategy by presenting uniqueness as the basis for development, iii) brand loyalty model is largely determined by customer satisfaction, brand awareness, service quality and brand image, iv) development planning by managing all resources through the management function by involving the tourism stakeholder Penta helix.
\end{abstract}

Keywords: Rural Tourism; Brand Loyalty Model; Art and Cultural Tourism Potency

\section{INTRODUCTION}

Bali is a world tourist destination that continues to be developed by the Government of the Republic of Indonesia. The development of tourism in Bali today leads to the concept of sustainability. A balance of economic, socio-cultural and environmental conditions are the three pillars that must be realized for this sustainability. Sustainable tourism will provide prosperity, improvement of the socio-cultural life of the community and environmental sustainability. Without the balance of these three pillars, it is unlikely that Bali will continue to exist competing in the international tourism scene. This is even more so in the Covid-19 Pandemic situation, limiting the movement of people from one place to another. This creates a setback as well as a potential for tourism progress. The decline is of course in terms of income and employment which greatly impoverishes the lives of people who depend on the tourism sector. Potential progress is also very possible because 
in this situation all tourism stakeholders are improving themselves towards quality tourism.

Balinese art and culture are both uniqueness and strength in winning the competition between tourist destinations (Ardana, 2016). Without arts and culture, Bali will not be glimpsed by foreign or domestic tourists. The development of tourism in Bali must continue to be based on Balinese culture. Nowadays there is a commodification of culture, as a result of mass tourism and the capital system in tourism practices in Bali. The cheapness of the tour packages offered causes many low budget tourists, who come to Bali, are generally not interested in Balinese culture. This has resulted in a decline in high budget tourists (from Europe and America) who are generally very interested in Balinese culture. This condition can reduce the existence of Balinese culture as a mainstay tourist attraction (Utama \& Susanto, 2016).

From the conceptual side, until now the debate about brand loyalty. There are three views, (i) attitudinal, which sees loyalty as an attitude, (ii) behavioural, which sees customer loyalty as a behaviour, and (iii) composite, which sees loyalty as a combination of attitudes and behaviours. Likewise, the antecedents that form brand loyalty, especially in the tourism industry, still need to be developed. This study adds a destination image that emphasizes art and culture as an antecedent in addition to service quality and customer satisfaction. In the indicators of brand loyalty, an element of advocacy is added which is a manifestation of the success of the current marketing concept 4.0. This research is located at Desa Wanagiri Kauh, Tabanan as the second year research where (i)local government, (ii) Tourist Guide (Himpunan Pramuwisata Indonesia), and (iii) HILDIKTIPARI (Association of Indonesian Tourism Higher Education Institutions) as partners in formulating the village brand loyalty model in Bali as art and cultural tourism destination. The role of these three components is significant in realizing the satisfaction and loyalty of tourists.

The state of the art of this research is to reveal the view of the relationship between the development of sustainable tourism and the stages of assessing tourism potential, testing the theory of brand loyalty in developing potential development models, which is still a debate among academics in the tourism industry in Industry 4.0 competition The results of this study are expected to provide a novelty in the form of a brand loyalty model that can be used as a basis for policymaking for tourism stakeholders. Cultural tourism in Bali is a performance between local people, spiritual people, and tourists. The unique Balinese culture including dance, traditional music, architecture, carving, and painting as a differentiator among other tourist destinations is interesting Picard (1990). Tourism supports the preservation and development of culture in Bali, and Balinese culture develops tourism. Brand loyalty is a condition in which customers are loyal to a brand based on a series of attitudes (cognitive, affective, and conative) and behaviour (Evanschitzky \& Wunderlich, 2006; Oliver, 1999; Suhartanto, 2011; Tjiptono, 2014). Decisionmaking theory includes consumers' overall behaviour in purchasing decisionmaking, which includes thoughts, feelings, and actions before the product is purchased, at the time of making a purchase, consumed, until after consumption (Peter \& Olson, 2014; Suprapti, 2010). The Tri-Component Theory explains the attitude of consumers in responding to marketing activities and consumer experiences in using a product that consists of three components which include 
cognitive, affective, and conative (Peter \& Olson, 2014). Furthermore, (Wisnawa, Prayogi., et al., 2018) suggests that a person's attitude towards an object always acts as an intermediary for the response of the stimuli it gets. Before liking or disliking (affection component) to an object. After liking it, consumers make a purchase decision (conative component). Indicators used to measure brand loyalty in this study include (Dobni \& Zinkhan, 1990; Wisnawa, et al., 2018) : (i) cognitive, (ii) affective, (iii) conative, (iv) behaviour, (v) advocacy, which is the level of tourists' desire to defend Bali's image as art and cultural tourism destinations. Industry 4.0 and Marketing 4.0 Industry 4.0 is the fourth industrial revolution marked by rapid advances in information technology which have caused fundamental changes to various global business entities and consumer behavior (Ibarra et al., 2018). From the marketing side, required to move more quickly to use existing resources to create more value for customers (Kotler et al., 2017). The rapid development of information technology is an opportunity for business entities to increase customer loyalty not only at repeat business but at the level of advocacy. Destination Image is a series of brand associations that exist in consumers' memories including psychological, symbolism, meaning, message, and personification aspects (Aaker, 1996; Keller, 1993; Sudiarta, 2012). Brand image is influenced by direct experience and promotional communications are formed through brand associations with other entities such as companies, countries, distribution channels, people, places, or events. This experience further adds to knowledge, feelings that influence subsequent purchase decisions. Art and culture are the products of a tourist destination that can affect the image or image of a tourist destination (Middleton $\mathrm{V}$ \& Clarke, 2001; Yamasihita, 1999; Zhang, 2015). Destination image is an understanding of tourist destinations that involve consumer behavior, products, systems, marketing efforts, service quality, and strategies. In the end, the image of a destination can have a good impact, in the form of satisfaction and loyalty of tourists to tourists to come back and tell, defending all the good things about tourist destinations (Kotler et al., 2017; Middleton V \& Clarke, 2001). Indicators to measure destination image include (Chitty et al., 2007; Kandampully \& Suhartanto, 2003; Suhartanto, 2011; Zeithaml, 1988) : (i) Favorability of brand associationgood reputation; (ii) Favorability of brand association feeling of outstanding; (iii) Strength of brand association-art destination, (iv) Strength of brand associationculture destination, (iii) Uniqueness of brand association. Service Quality, service quality is an important strategy for the success and survival of business organizations (Parasuraman \& Grewal, 2000), because it can affect consumer purchasing behaviour and organizational performance (Tabaku \& Kushi, 2013) reveals there are five indicators in measuring service quality, namely reliable, responsive, empathy, assurance and tangible. To date, the servqual model from Parasuraman is the best and most popular model. Service quality has the ability to increase customer loyalty (Wu, 2014). Therefore service quality can be used as an antecedent or predictor to measure customer loyalty. The indicators used to measure service quality include (i) reliability, (ii) responsiveness, (iii) empathy, (iv) assurance, (v) tangible. Customer Satisfaction, Customer satisfaction is one of the objectives of marketing activities (Anderson et al., 2004), which connects the purchasing and consumption process with the post-purchase phenomenon. Satisfying customers is an important element in the marketing concept (Peter \& Olson, 2014) because it affects consumer purchasing behaviour in the future, 
profitability, and shareholder value (Back \& Parks, 2003).The research paradigm regarding customer satisfaction has shifted from the cognitive realm (Suhartanto, 2011; Wu, 2014), which defines customer satisfaction as the consumer's response to an evaluation of the difference between the main expectations and the actual performance of a product received after consuming it. The indicators for measuring customer satisfaction are as follows (Back, 2005; Li, 2006) : (i) comfort while using the product (ii) the correctness of making purchasing decisions (iii) reality is greater than expectations (iv) overall satisfaction with Balinese arts (v) Overal satisfaction with Balinese culture.

This research refers to previous research (Chi et al., 2009; Flynn \& Pearcy, 2001; Huh, 2006; Suhartanto, 2011). The whole research is research on brand loyalty, but using different constructs, on different research objects. Li(2006) uses the construct of customer satisfaction, quality alternatives, investment size, service quality and service value for cruise ship passengers in America. Suhartanto (2011) uses the constructs of customer satisfaction, service value, brand image, and service quality in hotels in Bandung. This study uses the constructs of service quality, brand image, brand awareness and customer satisfaction. This study includes brand awareness as a supporting construct, because it can strengthen brand loyalty based on Huh (2006) using image, service quality, destination awareness, and satisfaction on tourist destinations in Virginia. Chi et al. (2009) used the constructs of brand awareness, service quality, brand loyalty and purchase intention in the hotel industry in Minnesota, America. Research on sustainable tourism development refers to Grilli et al. (2021) find that tourists have an important role in supporting sustainability through awareness and willingness to pay more.

Moreover, Wondirad \& Ewnetu (2019) shows the important role of stakeholders, especially tourists and the involvement of local communities in realizing sustainability. Herera et al. (2018) revealed the important role of host and tourist perceptions in realizing sustainability. (Aquino et al., 2018) revealed the role of Tourism Social Entrepreneurship in realizing sustainability by maximizing profits and suppressing negative impacts on tourist destinations. And Sutawa (2012) shows the role of tourism positively impacts sustainability by empowering local communities in management tourism.

Based on the description above, the purpose of this study is to answer the following problems: i) what is the tourism potential of Wanagiri Kauh Tabanan Bali Village ?; ii) what is the strategy to develop the potential of Wanagiri Kauh, Tabanan Bali Village ?; iii) what is the brand loyalty model for Desa Wanagiri Kauh Tabanan Bali ?; iv) what is the model for developing the tourism potential of Wanagiri Kauh, Tabanan Bali Village?

\section{METHODOLOGY}

The population in this study are all tourists who have visited Bali. There are many considerations in compiling a sample from a population (Hinkin, 1995). One ratio of comparison for determining the number of samples is to look at the number of indicators in the question item and multiply by four to ten (Hair et al., 2010; Hoelter, 1983). Based on this, this study requires a sample size of between 80 to 200. There are 20 items used in this study. Testing the research model using SEM requires a large sample, because a small sample is considered less stable for estimation purposes (Hair et al., 2010). The critical sample size for testing the SEM 
model was 200. Sampling was carried out using probability sampling: proportional stratified random sampling. To increase the likelihood of filling out the questionnaire, the questionnaires were distributed online and offline. Qualitative methods were also used to enhance the findings of this study with a SWOT and indepth interviews

Picture 1. Conceptual Framework

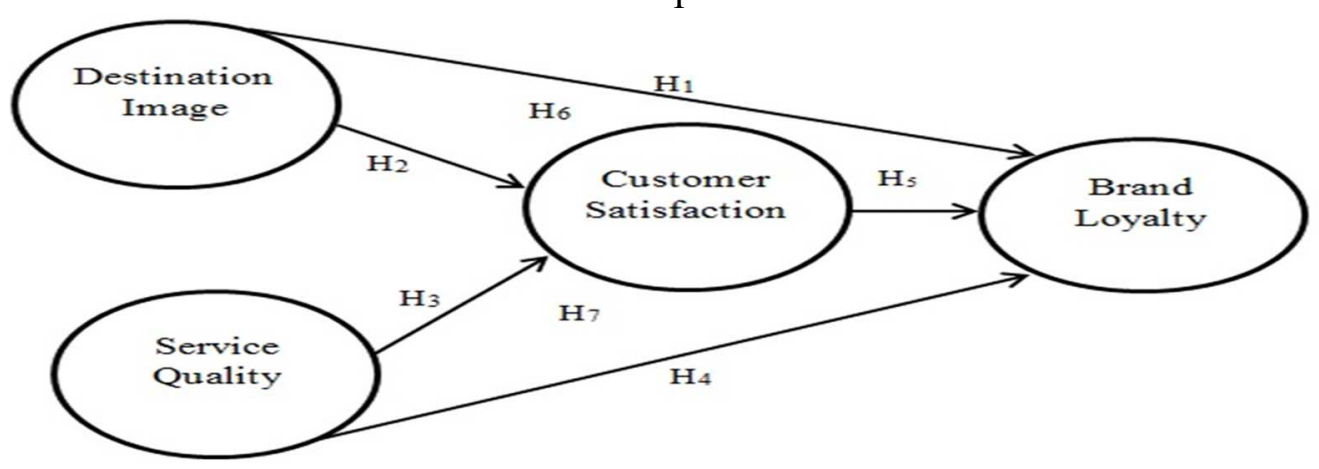

\section{RESULTS AND DISCUSSION}

\section{Tourism Potential of Wanagiri Kauh Village}

Wanagiri Kauh Village is located in Selemadeg District, Tabanan Regency, Bali Province. This village consists of several banjars including; Banjar Kerta, Banjar Kebon Bantiran, Banjar Mendek Banjar Kebon Tumpalan, Banjar Kebon Cempaka, and Banjar Kebon Anyar. The village area is 1,134 hectares, with $82 \%$ of rice fields and plantations, $15 \%$ of forest land and $2 \%$ of public facilities. Located at an altitude of $700 \mathrm{~m}$ above sea level, bordering Mount Batu Karu's protected forest in the north, Pupuan Sawah Village in the South, Wanagiri Village in the East and Karya Sari Village in the West. With a population of 2,243 people, most of them have junior high school and high school education (40\%).

There are two tourism potentials, namely natural tourism and cultural tourism. The potential for natural tourism includes: views of Mount Batu Karu in the north, views of Garuda Wisnu Kencana and Jimbaran Beach in the south, views of rice fields, coffee gardens, Titi Akah Waterfall, Kerta Waterfall, Giant Cave. The potential for cultural tourism includes: the life of farmers who adhere to Hinduism with Balinese customs. The life of traditional farmers relying on natural resources managed by Hindu belief systems and Balinese customs is a special attraction. The implementation of the panca yadnya ceremony consisting of the god yadnya, rsi yadnya, pitra yadnya, manusa yadnya and bhuta yadnya with the concept of Tri Hita Karana provides spiritual nuances and uniqueness for tourists to enjoy (Ardana, 2016; Mody et al., 2017; Utama \& Susanto, 2016) 


\section{Tourism Potency Development Strategy}

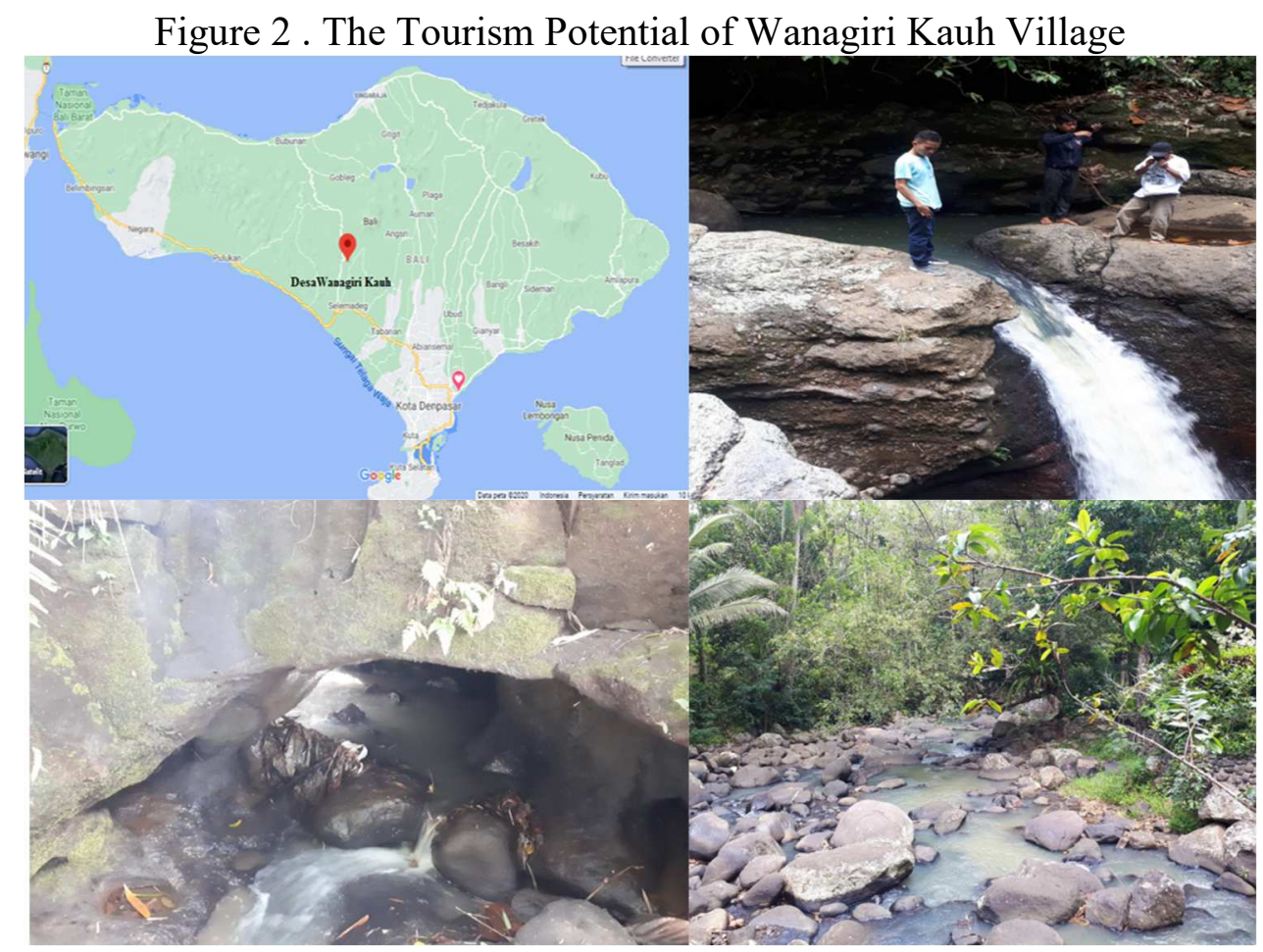

Source : Research result, 2020

Its strengths include: beautiful natural conditions, friendly attitude of the community, being in a strategic location between the Belimbing Village and Wanagiri Village where tourism is developing, as well as a paved entrance. The weaknesses that exist include: Some people are still not aware of tourism, no signposts are available, village boundaries are not clear, tourism facilities are still incomplete, and there is no institution that manages tourism. Opportunities that can be exploited include: the trend of allocentric tourists looking for new and natural tourism objects, the government is developing rural tourism, the name Bali is an international brand in the tourism sector, investors have started to invest in developing quality tourism (Foreign Policy Community of Indonesia, 2020; Grilli et al., 2020; Wondirad \& Ewnetu, 2019) and support from Belimbing and Wanagiri Villages to develop tourism in Wanagiri Kauh Village. Threats faced include: the tourism sector which is very vulnerable to issues, security and pandemics; capitalist investors, and competitors (Aquino et al., 2018; Herrera et al., 2018; Sutawa, 2012).

This study uses five variables, namely: Service Quality (SQ) is reflected in five statement items, Brand Image (BI) is reflected in five statement items, Brand Awareness (BA) is reflected in five statement items, Customer Satisfaction (CS) is reflected in four statement items and Brand Loyalty (BL) is reflected in the five statement items. The analysis conducted shows that all statement items from each variable have a calculated $r$ value greater than 0.3 with a significance of less than $5 \%$. Furthermore, Service Quality (SQ), Brand Image (BI), Brand Awareness (BA), Customer Satisfaction (CS), and Brand Loyalty (BL) were declared reliable with Cronbach's Alpha value greater than 0,6 (Ghozali, 2014) 
Identification of the respondents' characteristics was carried out to determine the description of the respondents involved in the research. The following is respondents' diversity based on gender, age, nationality, occupation, income, expenses during the trip, activities undertaken, the purpose of the trip, and length of visit made. This is expected to provide a relatively clear picture of the respondent's condition and its relation to the problem and research objectives, shown in Table 1.

Table 1. Respondent Characteristics

\begin{tabular}{|c|c|c|c|}
\hline & Characteristics & Amount & Percentage(\%) \\
\hline 1. & $\begin{array}{l}\text { Sex } \\
\text { Man } \\
\text { Woman }\end{array}$ & $\begin{array}{l}115 \\
85\end{array}$ & $\begin{array}{l}57.5 \\
42.5\end{array}$ \\
\hline 2. & $\begin{array}{l}\text { Age } \\
17 \text { to } 25 \text { years old } \\
26 \text { to } 35 \text { years old } \\
36 \text { to } 45 \text { years old } \\
46 \text { to } 55 \text { years old } \\
\text { More than } 55 \text { years old }\end{array}$ & $\begin{array}{l}105 \\
36 \\
44 \\
14 \\
1\end{array}$ & $\begin{array}{l}52.5 \\
18 \\
22 \\
7 \\
0.5\end{array}$ \\
\hline 3. & $\begin{array}{l}\text { Nationality } \\
\text { Africa } \\
\text { Asean } \\
\text { Indonesian }\end{array}$ & $\begin{array}{l}1 \\
2 \\
197\end{array}$ & $\begin{array}{c}0.5 \\
1 \\
98.5\end{array}$ \\
\hline 4. & $\begin{array}{l}\text { Job } \\
\text { Work while studying } \\
\text { Others } \\
\text { Civil servants } \\
\text { Private employees } \\
\text { Profesional (Dokter, Lecturer, Advocate, Hotelier, Guide dil) } \\
\text { Entrepreneur }\end{array}$ & $\begin{array}{l}46 \\
65 \\
30 \\
30 \\
12 \\
17\end{array}$ & $\begin{array}{l}23 \\
32.5 \\
15 \\
15 \\
6 \\
8.5\end{array}$ \\
\hline 5. & $\begin{array}{l}\text { Income (Million Rupiahs) } \\
1 \text { to } 2 \\
\text { Less than } 1 \\
\text { Less than } 5 \text { to } 10 \\
\text { More than } 10 \\
\text { Morethan } 2 \text { to } 5\end{array}$ & $\begin{array}{l}41 \\
74 \\
26 \\
6 \\
53\end{array}$ & $\begin{array}{l}20.5 \\
37 \\
13 \\
3 \\
26.5\end{array}$ \\
\hline 6. & $\begin{array}{l}\text { Travel Expenses (Thousand Rupiahs) } \\
100 \text { to } 200 \\
\text { Less than } 100 \\
\text { Less than } 500 \text { to } 1.000 \text {. } \\
\text { More than } 1.000 \text {. } \\
\text { More than } 200 \text { to } 500\end{array}$ & $\begin{array}{r}81 \\
45 \\
24 \\
7 \\
43\end{array}$ & $\begin{array}{l}40.5 \\
22.5 \\
12 \\
3.5 \\
21.5\end{array}$ \\
\hline 7. & $\begin{array}{l}\text { Tourist activities are carried out through } \\
\text { Travel Agent } \\
\text { Individual } \\
\text { Others } \\
\text { Virtual Tour }\end{array}$ & $\begin{array}{l}8 \\
138 \\
13 \\
41\end{array}$ & $\begin{array}{c}4 \\
69 \\
6.5 \\
20.5\end{array}$ \\
\hline 8 & $\begin{array}{l}\text { Travel Purposes } \\
\text { Learning tourism } \\
\text { Others } \\
\text { Doing tourist activities }\end{array}$ & $\begin{array}{l}30 \\
20 \\
150\end{array}$ & $\begin{array}{l}15 \\
10 \\
75\end{array}$ \\
\hline 9. & $\begin{array}{l}\text { Length of visits } \\
\text { Less than one day ( } 24 \text { hours) } \\
\text { More than one day }\end{array}$ & $\begin{array}{c}187 \\
13\end{array}$ & $\begin{array}{c}93.5 \\
6.5\end{array}$ \\
\hline 10. & $\begin{array}{l}\text { Number of visits } \\
\text { Twice } \\
\text { More than twice }\end{array}$ & $\begin{array}{c}176 \\
24\end{array}$ & $\begin{array}{l}88 \\
12 \\
\end{array}$ \\
\hline Total & & 200 & 100 \\
\hline
\end{tabular}

Based on the questionnaire distributed to tourists who have visited Wanagiri Kauh Village directly or through virtual tours, the following data were obtained: The characteristics of the respondents show that some tourists are male $(57.5 \%)$, young $(52.5 \%)$, Indonesian $(98.5 \%)$, working while studying $(23 \%)$, with an income of less than 5 million rupiah $(73,5 \%)$, tourism expenditure is less than five hundred thousand rupiah (83.5\%), manages tourism activities individually (69\%), the purpose of tourism is to carry out tourism activities $(75 \%)$, length of stay is less than one day $(93.5 \%)$ with the number of visits twice $(88 \%)$.

\section{Goodness of Fit Criteria Evaluation}

1. Data normality evaluation

Based on the results of calculations obtained from the output of the Amos 24.0 program in this research data, the value of the critical ratio curve for all 
indicators is in the range of \pm 2.58 . This means that all data used in this study are normally distributed, as in Table 2 below:

Tabel 2. Normality Test

\begin{tabular}{|c|cccccc|}
\hline Variable & $\min$ & $\max$ & skew & c.r. & kurtosis & c.r. \\
\hline BI5 & 1,000 & 5,000 &,- 359 & $-2,073$ &,- 094 &,- 271 \\
BA2 & 1,000 & 5,000 &,- 399 & $-2,302$ &, 271 &, 781 \\
BI4 & 1,000 & 5,000 &,- 475 & $-2,744$ &, 273 &, 787 \\
BI3 & 1,000 & 5,000 &,- 303 & $-1,752$ &, 203 &, 586 \\
BI2 & 1,000 & 5,000 &,- 402 & $-2,455$ &, 905 & 2,501 \\
BI1 & 2,000 & 5,000 &,- 312 & $-1,802$ &,- 475 & $-1,370$ \\
SQ5 & 1,000 & 5,000 &,- 229 & $-1,322$ &,- 329 &,- 950 \\
SQ4 & 1,000 & 5,000 &,- 425 & $-2,567$ &, 742 & 2,142 \\
SQ3 & 1,000 & 5,000 &,- 413 & $-2,515$ &,- 087 &,- 252 \\
SQ2 & 1,000 & 5,000 &,- 149 &,- 861 &, 197 &, 568 \\
BL4 & 1,000 & 5,000 &, 038 &, 219 &,- 268 &,- 774 \\
BL3 & 1,000 & 5,000 &,- 410 & $-2,369$ &,- 083 &,- 240 \\
BL1 & 1,000 & 5,000 &,- 264 & $-1,521$ &,- 426 & $-1,230$ \\
CS4 & 1,000 & 5,000 &,- 419 & $-2,545$ &, 461 & 1,330 \\
CS2 & 2,000 & 5,000 &,- 166 &,- 956 &,- 360 & $-1,038$ \\
CS1 & 1,000 & 5,000 &,- 396 & $-2,286$ &,- 014 &,- 039 \\
BA5 & 1,000 & 5,000 &,- 374 & $-2,158$ &,- 236 &,- 683 \\
BA3 & 2,000 & 5,000 &,- 262 & $-1,511$ &,- 512 & $-1,477$ \\
BA1 & 1,000 & 5,000 &,- 418 & $-2,543$ &,- 119 &,- 344 \\
Multivariate & & & & & 124,623 & 31,195 \\
\hline
\end{tabular}

Source : Research Result, 2020

2. Outlier Evaluation

In Table 3, it can be seen that the Mahalanobis distance value does not exceed 43.82 compared to the chi-square value with a significance level of 0.001 , degree of freedom 15 or $\chi^{2}(19 ; 0.001)=43.82$. This shows that there is no multivariate outlier problem in this study.

Tabel 3 Outlier Test

\begin{tabular}{|l|c|c|c|}
\hline Observation Number & $\begin{array}{c}\text { Mahalanobis d- } \\
\text { squared }\end{array}$ & $\mathrm{p} 1$ & $\mathrm{p} 2$ \\
\hline 187 & 25,267 &, 152 &, 004 \\
25 & 25,231 &, 153 &, 003 \\
52 & 24,714 &, 170 &, 012 \\
17 & 17,481 &, 557 &, 983 \\
80 & 17,386 &, 564 &, 985 \\
160 & 17,231 &, 574 &, 990 \\
171 & 17,231 &, 574 &, 986 \\
\hline
\end{tabular}




\begin{tabular}{|l|l|l|l|}
$\ldots \ldots$ & $\ldots \ldots$ & $\ldots \ldots$ & $\ldots \ldots$ \\
17 & 17,481 &, 557 &, 983 \\
80 & 17,386 &, 564 &, 985 \\
160 & 17,231 &, 574 &, 990 \\
171 & 17,231 &, 574 &, 986 \\
\hline
\end{tabular}

Source : Research Result, 2020

\section{Evaluasi Multicollinearity dan Singularity}

Multicollinearity dan singularity dapat dideteksi melalui determinan matrix covarian yang sama dengan nol (Ghozali, 2014). Data dalam penelitian ini terbebas dari hal tersebut, karena nilai matriks kovarian sebesar 0,00037

\section{Brand Loyalty Model}

This study uses Structural Equation Modeling (SEM) analysis with the software used for this research is IBM SPSS AMOS (Ghozali, 2014; Hair et al., 2010). The theoretical model described in the path diagram will be analyzed based on the data obtained.

\section{Model Measurement}

Model testing is conducted to test the relationship shown between indicators and their latent variables. Measurement model testing is done before all latent variables are tested together. In addition, the structural and measurement model testing allows the researcher to test measurement error as an inseparable part of SEM and perform factor analysis along with hypothesis testing (Ghozali, 2014; Hair et al., 2010; Hoelter, 1983). In the measurement model test, the results obtained Chi-square, Probability, GFI, AGFI, CFI, TLI, and RMSEA (Ghozali, 2014).

Tests are carried out on endogenous variables together, namely brand awareness, customer satisfaction and brand loyalty. The results of the measurement model test can be seen in Figure 3:

Figure 3: Endogenous Variable Measurement Model

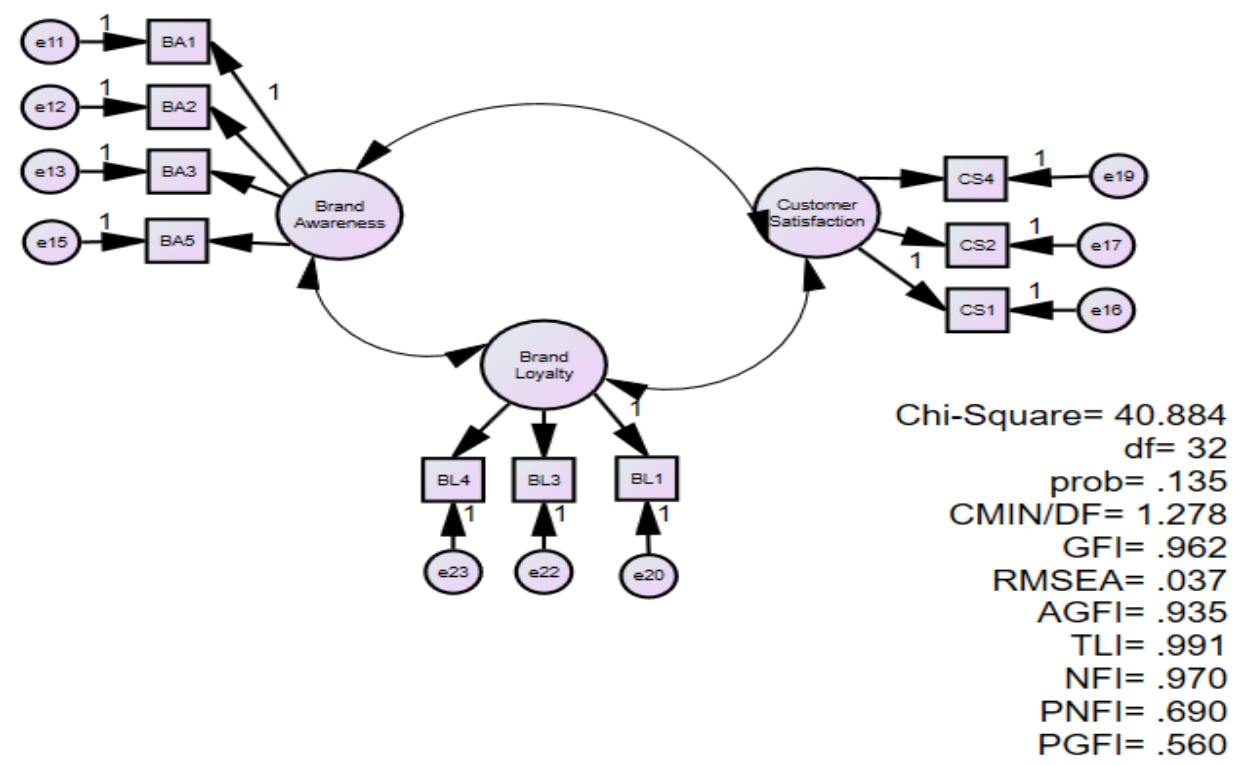

Source : Research Result, 2020 
Testing of the model hypothesis shows that this model is in accordance with the data or fit the data used in this study. Even though the Chi-Square value is quite large 40.884. Chi Square value is affected by the degree of freedom value. In this study the degree of freedom value is 32 . If the degree of freedom value is smaller, the Chi-Square value will decrease. However, to meet the probability criteria, several indicators of endogenous variables must be issued so that the model can meet the probability criteria greater than 0.0544 (Ghozali, 2014; Hair et al., 2010). The indicators issued from each variable are BA4 from the brand awareness variable, CS3 from the customer satisfaction variable and BL2 and BL5 from the brand loyalty variable. From the reduction of indicators that have a high correlation, a probability value of 0.135 is obtained, a CMIN / DF value of 1.278 is smaller than 2, a GFI of 0.962 is greater than 0.90, an AGFI value of 0.935 is greater than 0.90 , a TLI value of 0.991 is greater than 0.90 and the RMSEA value is 0.037 less than 0.08 . From the results of this analysis it can be concluded that the endogenous measurement variable model can be declared feasible for testing the structural model (Ghozali, 2014; Hair et al., 2010). This corresponds to Latif et al. (2014), Tabaku \& Kushi (2013)

Figure 4. Model of Brand Loyalty for Tourists Visiting Wanagiri Kauh Village

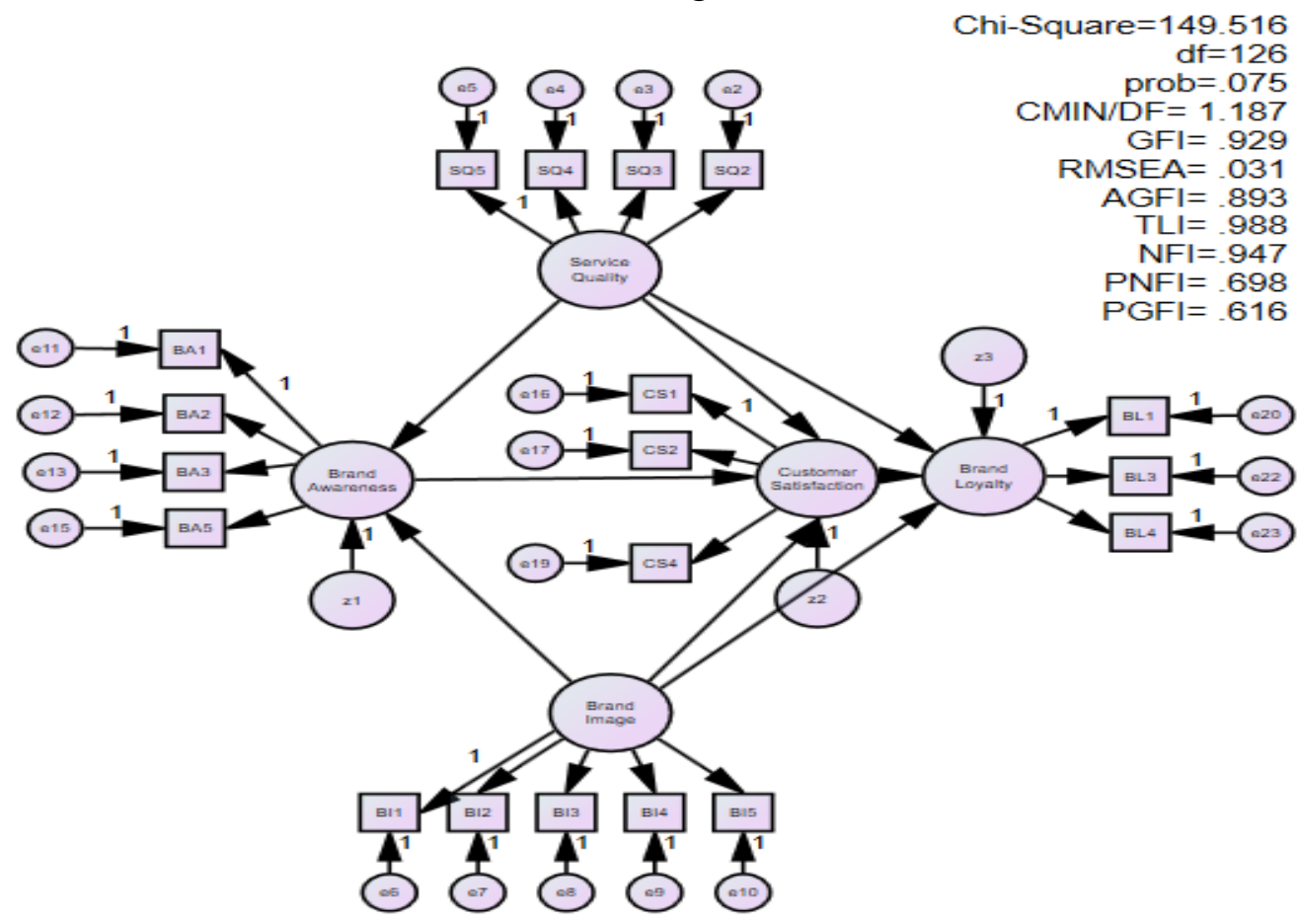

Source : Research result, 2020

Figure 4 shows that the brand loyalty model of tourists visiting Wanagiri Kauh Village is formed from customer satisfaction, brand image, service quality and brand awareness. This finding is consistent with research from Huh (2006) and Chi et al. (2009). Table 4 shows that brand loyalty is determined by customer satisfaction and brand image with an error rate of less than $5 \%$. 
Table 4 The relationship between the variable brand loyalty of tourists visiting Wanagiri Kauh Village

\begin{tabular}{|r|ll|c|c|c|c|}
\hline No & \multicolumn{2}{|c|}{ Variables } & Estimate & Standard Error & Critical Ratio & Significance \\
\hline 1 & Service_Quality & $\rightarrow$ Brand_Awareness & $-0,061$ & 0,161 & $-0,382$ & 0,703 \\
2 & Brand_Image & $\rightarrow$ Brand_Awareness & 1,246 & 0,2 & 6,247 & $* * *$ \\
3 & Service_Quality & $\rightarrow$ Customer_Satisfaction & 0,325 & 0,134 & 2,43 & 0,015 \\
4 & Brand_Image & $\rightarrow$ Customer_Satisfaction & 0,075 & 0,277 & 0,27 & 0,787 \\
5 & Brand_Awareness & $\rightarrow$ Customer_Satisfaction & 0,61 & 0,178 & 3,437 & $* * *$ \\
6 & Customer_Satisfaction & $\rightarrow$ Brand_Loyalty & 0,696 & 0,161 & 4,317 & $* * *$ \\
7 & Service_Quality & $\rightarrow$ Brand_Loyalty & $-0,058$ & 0,153 & $-0,379$ & 0,705 \\
8 & Brand_Image & $\rightarrow$ Brand_Loyalty & 0,539 & 0,209 & 2,583 & 0,01 \\
\hline
\end{tabular}

Source : Research result, 2020

Furthermore, by paying attention to the tourist brand loyalty model, a model for developing the tourism potential of Wanagiri Kauh Village is compiled as in Figure 5 below

Figure 5. Tourism Potential Development Model for Wanagiri Kauh Tourism Village

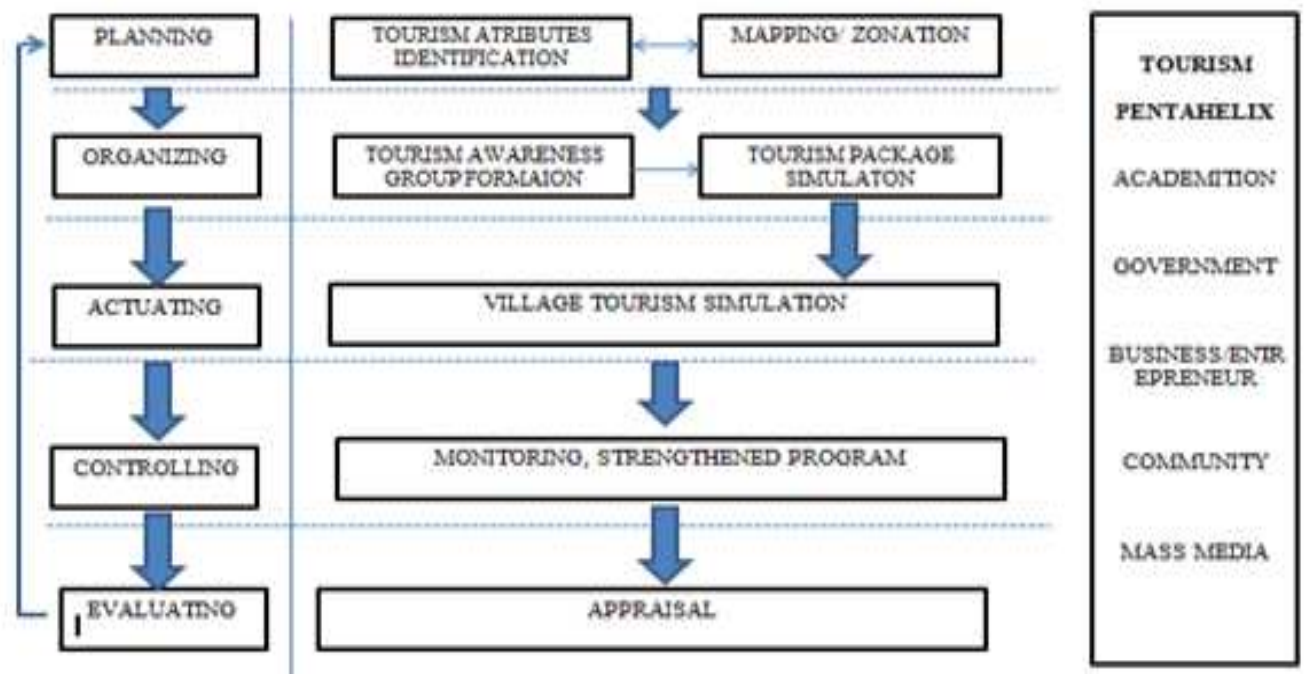

Source : Research result, 2020

At the planning stage, (i) identification of tourist attraction attributes which include: attraction, accessibility, amenities, ancillary and community involvement, and (ii) mapping / zoning in the form of village area planning with attention to local wisdom without changing land functions, especially holy areas. This stage involves the tourism Penta helix which includes: academics, government, entrepreneurs, hobby communities and mass media.

At the organizing stage, a tourism awareness group (Pokdarwis) was formed by involving community leaders, PKK groups and youth organizations. Furthermore, a simulation of tour packages will be made which includes tracking 
packages and agro-tourism packages. The tracking package will include an itinerary which includes seeing (i) views of Mount Batu Karu, Garuda Wisnu Kencana Statue, Jimbaran Beach, views of rice terraces and (ii) attractions of Balinese gamelan and dance attributes. The agro-tourism package consists of managing rice fields and coffee gardens. The entire tour package includes a culinary tour of Wanagiri Kauh Village's typical food, namely komoh, timbungan and sequence.

At the actuating stage, the Pokdarwis will be briefed on the technicalities of serving tourists, which includes the following aspects: (i) understanding tourism villages (ii) tour guides, (iii) food and beverage services, (iv) food and beverage production, (v) homestay services.

At the control stage, the supervision that is attached to the simulation process is carried out, where as many as 30 tourists are brought in to enjoy the simulation of the tour packages offered. Control is based on the standards set in every aspect of the service that has been provided at the actuating stage. Tourists will also be asked for their opinion about the tour package simulations offered using interview, survey and focus group discussion techniques.

At the evaluation stage, an assessment will be carried out of each stage carried out, so that it can be refined again until it reaches the right model for developing tourism potential. All stages involve tourism stakeholders in Wanagiri Kauh Village, which include: (i) government, (ii) academics, (iii) entrepreneurs, (iv) communities and (v) mass media.

\section{CONCLUSION}

Wanagiri Kauh Village's tourism potential consists of natural tourism and cultural tourism that could be developed by uniqueness. The brand loyalty model is formed from tourist satisfaction, the village image, tourist awareness and service quality. The development of the potential for sustainable tourism in Wanagiri Kauh Village could be done by involving all tourism stakeholders, from planning, organizing, implementing, controlling and evaluating. Theoretically, this study contributes to tourism science in tourism marketing management combined with sustainable development through studies in rural areas. Practically this research provides input to villages in developing sustainable tourism potential through identification of tourism potential, tourist perceptions of loyalty, and development models for tourism to be sustainable. This study's weakness lies in the limited literature regarding tourist perceptions of loyalty to rural tourism areas. Likewise, the data collection process carried out during this pandemic through a virtual tour. Even though a virtual tour is the best alternative solution, it only involves the senses of sight, hearing and imagination. Meanwhile the real tour involves a complete sensing component, so the results are certainly more valid. Further research can be carried out in villages with the category of pilot, advanced, developing and independent. Thus it can be compared the potentials, strengths, weaknesses, opportunities, threats, perceptions of tourists towards loyalty and in the end a sustainable tourism development model can be determined.

\section{ACKNOWLEDGEMENT}

Thanks to the Government of the Republic of Indonesia who funded this research through the Directorate General of Research and Community Service of the Higher Education in 2020, along with the institutions and the entire STIPAR 
Triatma Jaya academic community who gave enthusiasm and time so that this research could be completed.

\section{REFERENCES}

Aaker, D. (1996). Building Strong Brand. New York. Free Pres. Hal. 106 Dikutip dalam buku Freddy Rangkuti. 2002. The Power of Brand, 162-166.

Anderson, E. W., Fornell, C., \& Mazvancheryl, S. K. (2004). Customer Satisfaction and Shareholder Value. Journal of Marketing, 68(4), 172-185.

Aquino, R. S., Lück, M., \& Schänzel, H. A. (2018). A conceptual framework of tourism social entrepreneurship for sustainable community development. Journal of Hospitality and Tourism Management, 37, 23-32.

Ardana, I. K. (2016). Bali Jadi Destinasi Favorit Masyarakat di Eropa di Liburan Akhir Tahun. https://www.merdeka.com/uang/bali-jadi-destinasi-favoritmasyarakat-eropa-di-liburan-akhirtahun.html

Back, K.-J. (2005). The effects of image congruence on customers' brand loyalty in the upper middle-class hotel industry. Journal of Hospitality \& Tourism Research, 29(4), 448-467.

Back, K.-J., \& Parks, S. C. (2003). A brand loyalty model involving cognitive, affective, and conative brand loyalty and customer satisfaction. Journal of Hospitality \& Tourism Research, 27(4), 419-435.

Chi, H., Yeh, H. R., \& Yang, Y. (2009). The Impact of Brand Awareness on Consumer Purchase Intention: The Mediating Effect of Perceived Quality and Brand Loyalty. The Journal of International Management. http://www.academia.edu/download/34707438/17_ya_ting_yang. pdf

Chitty, B., Ward, S., \& Chua, C. (2007). An application of the ECSI model as a predictor of satisfaction and loyalty for backpacker hostels. Marketing Intelligence \& Planning.

Dobni, D., \& Zinkhan, G. M. (1990). In search of brand image: A foundation analysis. ACR North American Advances.

Evanschitzky, H., \& Wunderlich, M. (2006). An examination of moderator effects in the four-stage loyalty model. Journal of Service Research, 8(4), 330-345.

Flynn, L. R., \& Pearcy, D. (2001). Four subtle sins in scale development: some suggestions for strengthening the current paradigm. International Journal of Market Research, 43(4), 1-14.

Foreign Policy Community of Indonesia. (2020). The Economic Impact of COVID19 Outbreak on Indonesia. http://www.fpcindonesia.org/wpcontent/uploads/2020/04/FPCI-SpecialUpdate-The-Economic-Impact-ofCOVID-19-Outbreak-on-Indonesia.pdf

Ghozali, I. (2014). Model Persamaan Struktural: Konsep dan Aplikasi dengan Program AMOS 22.0 Update Bayesian SEM. Semarang: Badan Penerbit Universitas Diponegoro.

Grilli, G., Tyllianakis, E., Luisetti, T., Ferrini, S., \& Turner, R. K. (2020). Prospective tourist preferences for sustainable tourism development in Small Island Developing States. Tourism Management, 82, 104178.

Hair, J. F., Black, W. C., Babin, B. J., \& Anderson, R. E. (2010). Multivariate Data Analysis: A Global Perspective Upper Saddle River (7th ed.). Pearson Education. 
Herrera, M. R. G., Sasidharan, V., Hernández, J. A. Á., \& Herrera, L. D. A. (2018). Quality and sustainability of tourism development in Copper Canyon, Mexico: Perceptions of community stakeholders and visitors. Tourism Management Perspectives, 27, 91-103. https://doi.org/10.1016/j.tmp.2018.05.003

Hinkin, T. R. (1995). A Review of Scale Development Practices in The Study of Organizations. Journal of Management, 21(5), 967-988.

Hoelter, J. W. (1983). The Analysis of Covariance Structures: Goodness-of-Fit Indexes. Sociological Methods and Research, 11(2), 325-344.

Huh, J. (2006). Destination Branding As An Informational Signal and Its Influence on Satisfaction and Loyalty in The Leisure Tourism Market. Faculty of Virginia Polytechnic Institute and State University.

Ibarra, D., Ganzarain, J., \& Igartua, J. I. (2018). Business model innovation through Industry 4.0: A review. Procedia Manufacturing, 22, 4-10. https://doi.org/10.1016/j.promfg.2018.03.002

Kandampully, J., \& Suhartanto, D. (2003). The Role of Customer Satisfaction and Image in Gaining Customer Loyalty in The Hotel Industry. Journal of Hospitality \& Leisure Marketing, 10(3).

Keller, K. . (1993). Conceptualizing, Measuring, and Managing Customer Based Brand Equity. Journal of Marketing, 57(1), 1-22. https://doi.org/http://dx.doi.org/10.237/1252054

Kotler, P., Setiawan, I., \& Kertajaya, H. (2017). Marketing 4.0 : Moving from Traditional to Digital. John Willey and Sons.

Latif, W. B., Islam, M. A., \& Idris Bin, M. N. (2014). A Conceptual Framework to Build Brand Loyalty in The Modern Marketing Environment. Journal of Asian Scientific Research, 4(10), 547-557.

Li, X. (2006). Examining The Antecedents and Structure of Customer Loyalty in A Tourism Context. Texas A\&M University.

Middleton V, C., \& Clarke, J. (2001). Marketing in Travel and Tourism. Oxford.

Mody, M., Day, J., Sydnor, S., Lehto, X., \& Jaffé, W. (2017). Integrating country and brand images: Using the product-Country image framework to understand travelers' loyalty towards responsible tourism operators. Tourism Management Perspectives, 24, 139-150. https://doi.org/10.1016/j.tmp.2017.08.001

Oliver, R. L. (1999). Whence Consumer Loyalty? Journal of Marketing, 63(1), 3344.

Parasuraman, A., \& Grewal, D. (2000). The Impact of Technology on The QualityValueLoyalty Chain: A Research Agenda. Journal of Academic Marketing Science, 28(1), 168-174.

Peter, J. P., \& Olson, J. . (2014). Perilaku Konsumen dan Strategi Pemasaran (9th ed.). Salemba Empat.

Picard, M. (1990). "Cultural Tourism" in Bali: Cultural Performances as Tourist Attraction. Indonesia, 49, 37. https://doi.org/10.2307/3351053

Sudiarta. (2012). Membangun Citra Destinasi Wisata Seberapa Pentingkah? Jurnal Ekonomi Dan Pariwisata Universitas Dhyana Pura, 7(1), 60-76.

Suhartanto, D. (2011). An Examination of The Structure and Determinants of Brand Loyalty across Hotel Brand Origin. ASEAN Journal on Hospitality and Tourism, 10(2), 146-161. 
Suprapti, N. W. S. (2010). Perilaku Konsumen Pemahaman Dasar dan Aplikasinya Dalam Strategi Pemasaran. Udayana University Press.

Sutawa, G. K. (2012). Issues on Bali Tourism Development and Community Empowerment to Support Sustainable Tourism Development. Procedia Economics and Finance, 4, 413-422. https://doi.org/10.1016/S22125671(12)00356-5

Tabaku, E., \& Kushi, E. (2013). Service Quality, Customer Satisfaction, Perceived Value and Brand Loyalty: A Critical Review of The Literature. Academic Journal of Interdiciplinary Studies, 2(9).

Tjiptono, F. (2014). Pemasaran Jasa. Andi.

Utama, I. R., \& Susanto, P. . (2016). Faktor Faktor Penarik Wisatawan Asal Eropa ke Bali. https://www.researchgate.net/profile/Rai_Utama_I_Gusti_Bagus/publicatio n/311451199_FAKTORFAKTOR_PENARIK_WISATAWAN_ASAL_ER OPA_BERWISATA_KE_BALI/links/58 46ce0708ae8e63e6307e68/FAKTOR-FAKTOR-PENARIKWISATAWAN-ASALEROPA-BERWISATA-KE-BALI

Wisnawa, I. M. B., Antara, I. . M., \& Bendesa, I. (2018). Brand Awareness at Chain Hotel in Bali : A Case Study at Inna Hotel Group. IJMER, 7(1), 4.

Wisnawa, I. M. B., Prayogi., I. P. A., Sumerta., I. K. ., \& Aristana, I. N. (2018). Customer Brand Loyalty at Bali Art Festival. International Journal of Multidisciplinary and Educational Research (IJMER), 7(8), 282-301. http://s3-ap-southeast1.amazonaws.com/ijmer/pdf/volume7/volume7issue8(2)-2018.pdf

Wondirad, A., \& Ewnetu, B. (2019). Community participation in tourism development as a tool to foster sustainable land and resource use practices in a national park milieu. Land Use Policy, 88, 104155. https://doi.org/10.1016/j.landusepol.2019.104155

$\mathrm{Wu}, \mathrm{H}$. (2014). The Effects of Customer Satisfaction, Perceived Value, Corporate Image and Service Quality on Behavioral Intentions in Gaming Establishments. Asia Pacific Journal of Marketing and Logistics, 26(4), 540565.

Yamasihita, S. (1999). Bali Cultural Tourism and Touristic Culture. USA: Southeast Asia Program Publications at Cornell, 177-182. https://www.jstor.org/stable/3351053Schiffman dan Kanuk (2008))

Zeithaml, V. A. (1988). Consumer Perceptions of Price, Quality, and Value: A Means-End Model and Synthesis of Evidence. Journal of Marketing, 52(3), $2-22$.

Zhang, Y. (2015). The Impact of Brand Image on Consumer Behavior: A Literature Review. Open Journal of Business and Management, 03(01), 58-62. https://doi.org/10.4236/ojbm.2015.31006 